\title{
Leptin concentrations in Jezersko-Solchava lambs and growing rams
}

\author{
V. Cestnik ${ }^{1,3}$, N. Čebulj-Kadunc ${ }^{1}$ and M. Kosec ${ }^{2}$ \\ ${ }^{1}$ Institute of Physiology, Pharmacology and Toxicology, \\ ${ }^{2}$ Clinic for Reproduction and Horses, \\ Veterinary Faculty, University of Ljubljana \\ P.O. Box 3425, 1115 Ljubljana, Slovenia
}

\begin{abstract}
Plasma leptin concentrations were measured by a commercial multi-species RIA kit in JezerskoSolchava lambs aged 5 days to 3 months and in rams aged 3 to 12 months. The results were in accordance with the values measured in other breeds of sheep, no sexual dimorphism was detected. A significant increase of plasma leptin concentrations was observed from the $2^{\text {nd }}$ to $12^{\text {th }}$ month of life.
\end{abstract}

KEY WORDS: leptin, growth, lambs, rams

\section{INTRODUCTION}

Leptin is primarily produced in white adipose tissue in response to the changes in body weight and energy. The effects of leptin can be expressed through direct influences within neural or peripheral tissues or through interactions with other hormones (Houseknecht et al., 1998). In growing and lactating ruminants plasma leptin concentrations is dynamically regulated by several physiological states and environmental factors, such as variations in nutrition and adiposity, changes in nutrient Houseknecht et al., 1998; fluxes and metabolic changes associated with pregnancy, lactation and infection (Houseknecht et al., 1998; Erhardt et al., 2000; Chilliard et al., 2001). The aim of our work was to determine plasma leptin levels in Jezersko-Solchava, a Slovenian autochthonous breed of sheep and to determine plasma leptin changes related to the age and sex of the animals.

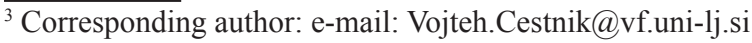




\section{MATERIAL AND METHODS}

The study was performed in Jezersko-Solchava lambs (25 males and 22 females) aged from 5 days to 3 months, stalled together with their dams and in 48 Jezersko-Solchava rams aged 4 to 12 months, age-grouped in stall boxes. Animals had free access to hay, fresh water and commercial sheep mineral mixture. Blood samples of all animals were taken on the same day (mid-May) by jugular venipuncture, using evacuated tubes with EDTA as anticoagulant (Vaccuete; Greiner Labortechnik, Austria). Plasma was kept frozen until analysed. Leptin concentrations were measured by a commercial RIA kit (Multi-species leptin RIA kit, Linco Research, USA). Statistical evaluations were performed by a computer programme (Microsoft ${ }^{\circledR}$ Excel, Microsoft Corporation 1985-2001) with subprogrammes Paired t-test, descriptive statistics and analysis of variance. Results were considered as significant at $\mathrm{P}<0.05$ and presented as mean \pm SEM.

\section{RESULTS}

Mean plasma leptin concentration for ram lambs was $0.83 \pm 0.05 \mathrm{ng} / \mathrm{mL}$ and for ewe lambs $0.84 \pm 0.06 \mathrm{ng} / \mathrm{mL}(\mathrm{P}>0.05)$. Further calculations were therefore performed without considering the sex of the animals. Plasma leptin concentrations in lambs and rams of various age groups are represented in Table 1.

Table 1. Plasma leptin concentrations in lambs and rams of various ages, $\mathrm{ng} / \mathrm{mL}$

\begin{tabular}{lcc}
\hline $\begin{array}{l}\text { Age group } \\
\text { months }\end{array}$ & $\mathrm{n}$ & $\begin{array}{l}\text { Leptin } \\
\mathrm{ng} / \mathrm{mL}\end{array}$ \\
\hline 1 & 21 & $0.97 \pm 0.05$ \\
2 & 14 & $0.66 \pm 0.03$ \\
3 & 17 & $0.78 \pm 0.08$ \\
$4-5$ & 12 & $1.27 \pm 0.06$ \\
6 & 12 & $1.42 \pm 0.08$ \\
7 & 12 & $1.48 \pm 0.09$ \\
12 & 12 & $1.81 \pm 0.12$ \\
\hline
\end{tabular}

The lowest leptin concentration was determined at the age of 2 and the highest at the age of 12 months $(\mathrm{P}<0.001)$. Differences in plasma leptin values among various age groups were significant $(\mathrm{P}<0.001)$. Correlation between the plasma leptin values and the age of the animals was positive and significant $(\mathrm{r}=0.8987$; $\mathrm{P}<0.01)$. 


\section{DISCUSSION}

Plasma leptin concentration measured in Jezersko-Solchava lambs and growing rams are in accordance to the values measured in some other sheep breeds (Blache et al., 2000; Delavaud et al., 2000). Sexual dimorphism for plasma leptin is reported in prepuberal humans, horses and sheep (Erhardt et al., 2000; Cartmill et al., 2003), females having higher plasma concentrations than males. Comparing leptin concentrations in lambs of both sexes, there are no differences between ewe and ram lambs, which is also the case in mixed-parity lambs (McFadin et al., 2002).

The lowest plasma leptin concentration in Jezersko-Solchava lambs was determined at 2 months, followed by a significant increase till the $12^{\text {th }}$ month. Decreased leptin levels in lambs after the $5^{\text {th }}$ day of life ensure elevated appetite and adipose tissue deposition (Bispham et al., 2002). When approaching to the puberty the concentrations of leptin increase (McFadin et al., 2002). The progressive rising of leptin concentrations can be attributed to the elevation of fat content with growth, as plasma leptin concentrations in growing lambs are linearly related to the body fat contents (Erhardt et al., 2000).

\section{CONCLUSIONS}

Plasma leptin concentration measured in Jezersko-Solchava lambs and growing rams are in accordance to the values in other breeds of sheep. No sexual dimorphism for plasma leptin is evident in investigated lambs. A significant increase of plasma leptin concentrations was observed in growing rams from the $2^{\text {nd }}$ to $12^{\text {th }}$ month of life.

\section{REFERENCES}

Blache D., Tellam R.L., Chagas L.M., Blackberry M.A., Vercoe P.E., Martin G.B., 2000. Level of nutrition affects leptin concentrations in plasma and cerebrospinal fluid in sheep. J. Endocrinol. $165,625-637$

Bispham J., Budge H., Mostyn A., Dandrea J., Clarke L., Keisler D.H., Symonds M.E., Stephenson T., 2002. Ambient temperature, maternal dexamethasone, and postnatal ontogeny of leptin in the neonatal lamb. Pediat. Res. 52, 85- 90

Cartmill J.A., Thompson D.L., Gentry L.R., Pruett H.E, Johnson C.A., 2003. Effects of dexamethasone, glucose infusion, adenocorticotropin, and propylthiouracil on plasma leptin concentrations in horses. Domest. Anim. Endocrinol. 24, 1-14

Chilliard Y., Bonnet M., Delavaud C., Faulconnier Y., Leroux C., Djiane J., Bocquier F., 2001. Leptin in ruminants. Gene expression in adipose tissue and mammary gland, and regulation of plasma concentrations. Domest. Anim. Endocrinol. 21, 271-295

Delavaud C., Bocquier F., Chilliard Y., Keisler D.H., Gertler A., Kann G., 2000. Plasma leptin determination in ruminants: effect of nutritional status and body fatness on plasma leptin concentrations assessed by a specific RIA in sheep. J. Endocrinol. 165, 519-526 
Erhardt R.A., Slepetis R.M., Siegal-Willott J., Van Amburgh M.E., Bell A.W., Boisclar Y.R., 2000. Development of a specific radioimmunoassay to measure physiological changes of circulating leptin in cattle and sheep. J. Endocrinol. 166, 519-528

Houseknecht K.L., Baile C.A., Matteri R.L., Spurlock M.E., 1998. The biology of leptin: A review. J. Anim. Sci. 76, 1405-1420

McFadin E.L., Morrison C.D., Buff P.R., Whitley N.C., Keisler D.H., 2002. Leptin concentrations in periparturient ewes and their subsequent offspring. J. Anim. Sci. 80, 738-743 